\title{
COMPARATIVE ANALYSIS OF PROBLEMS MILITATING AGAINST CORPORATE SOCIAL RESPONSIBILITY IN SELECTED BANKS AND MANUFACTURING FIRMS IN NIGERIA
}

\author{
Olu Ojo $^{1}$
}

\author{
UDC / UDK: 174:658](669.1) \\ JEL classification / JEL klasifikacija: M14, A13, G21 \\ DOI: https://doi.org/10.22598/pi-be/2018.12.1. 73 \\ Preliminary communication / Prethodno priopćenje \\ Received / Primljeno: November 17, 2017 / 17. studenoga 2017. \\ Accepted for publishing / Prihvaćeno za tisak: June 11, 2018 / 11. lipnja 2018.
}

\begin{abstract}
Summary
This study Summary presents a comparative investigation of the problems militating against Corporate Social Responsibility (CSR) in selected commercial banks and manufacturing firms in Nigeria. A survey research design was used while purposive sampling method was employed to select five commercial banks and five manufacturing firms. Primary data were garnered with the aid of a questionnaire from 216 and 205 respondents from commercial banks and manufacturing firms respectively. Problems militating against the practice of CSR activities of selected companies were analysed using the Mann-Whitney $U$ Test as the analytical tool. The result shows that there is no significant difference between the problems militating against the practice of CSR in commercial banks and manufacturing firms in Nigeria. The reason is that for all the variables tested, the $p$ value is greater than 0.05 . The study recommends that corporate managers should properly address these problems, such as inadequate financial resources and unethical practices like inside dealings among others, in order to achieve the benefits of actively engaging in CSR such as enhancement of customers' loyalty and a positive corporate image.
\end{abstract}

Key words: Corporate social responsibility, Militating problems, Commercial banks, Manufacturing firms, Nigeria.

\footnotetext{
${ }_{1}$ Olu Ojo, Ph.D., Department of Business Administration. Faculty of Management Sciences, Osun State University, Okuku, Osun State, Nigeria, E-mail: oluojo@gmail.com; oluojoe@yahoo.com
} 


\section{INTRODUCTION}

Business organisations operate in environments characterised by dynamism, complexity, uncertainty and competitiveness. This means that business organisations do not exist in a vacuum. They derive their existence from the society. In some situations, business organisations must get what is generally referred to as a license to operate before they can be allowed to operate in the immediate environment. In recent times, society's expectations from businesses have increased (D'Amato, Henderson, \& Florence, 2009). Developments arising from environmental forces coupled with other problems such as cut-throat competition, stagnant demand, price instability, and shortage of raw materials among others affect business operations. Therefore, the need for organisations to survive in today's fiercely competitive market is causing many business managers to rethink the way they do business with the hope of remaining relevant to their stakeholders. (Idowu, 2012). Many Nigerian corporations have adopted Corporate Social Responsibility (CSR) as a strategy to legitimatise their existence and reposition their companies for better performance (Eweje, 2006).

Over the years, CSR has grown dramatically in many companies, irrespective of their size, ownership structures and nature of business, developing innovative CSR strategies (Ojo, 2015). Existing literature reveals a number of empirical studies on CSR in Nigeria, of which the majority concentrate on multinational oil companies in the Niger Delta (Amaeshi, Adi, Ogbechie, \& Amao, 2006). In addition, the emergence of stakeholders' theory and the demand for an organisation to be socially responsible has brought in a new panorama to business organisations. Companies are expected to imbibe the spirit of repaying the constituent members of their environment, including not only the shareholders but also all other stakeholders in general (Nwanji, 2005; Nwanji \& Howell, 2006; Jill, 2007). However, not all companies have imbibed the tenets of CSR as part of their business obligations. They are faced with myriads of problems that are making them lag behind in their CSR activities. This study presents a comparative examination of the problems militating against CSR activities of selected commercial banks and manufacturing firms in Nigeria.

\section{LITERATURE REVIEW}

\subsection{Conceptual Framework of Corporate Social Responsibility}

CSR as a concept is based on the premise that the responsibility of business organisations is more than the maximisation of shareholders' profit. Many definitions of CSR have been provided by different writers, making the concept fuzzier (Henderson, 2001; Gobbels, 2002; van Marrewijk, 2003) and open to a number of different and conflicting interpretations (Windsor, 2001; Ojo, 2008). Despite the fact that a number of definitions are available, the generally accepted way of describing social responsibility is the obligation of the business managers to the society (Idowu, 2014; Ojo, 2015). Jones and George (2003) define social responsibility as a manager's duty to make decisions and take actions that enhance and promote the welfare of all types of stakeholders and 
the community in general. European Commission [EC] (2001) defines CSR as a concept in which a company integrates social and environmental obligations in the operations of their business with the sole aim of interacting with the stakeholders in such a way that mutual interaction subsists between the organisation and the society and that this responsible behaviour leads to sustainable business success.

Although these definitions seem to be straightforward, CSR is difficult to understand as a concept. The reason is that there is no generally accepted view among different people with regard to actions that can contribute to the welfare of the society. If an organisation fails to perform its social responsibility, this can lead to sanctions from the government and stiff opposition from the society. Therefore, business organisations must have a positive impact on the society. One integral part of the social responsibility of an organisation is to make a positive impact that is meaningful and can reduce its negative influence on the society. However, only voluntary actions are qualified to be described as responsible actions (Kreitner, 1995).

\subsection{Approach to Corporate Social Responsibility}

In view of the controversy about whether or not a business should engage in social responsibility, it is not surprising to discover that a number of approaches or responses have been propounded for this issue. Organisations adopt four possible positions on social responsibility. Figure 1 illustrates the four stances that an organisation can take concerning its obligations to society, which fall along a continuum ranging from the lowest to the highest degree of socially responsible practices. This also shows the strength of an organisation's commitment to social responsibility.

Figure 1: Four Continuum Approaches to Social Responsibility

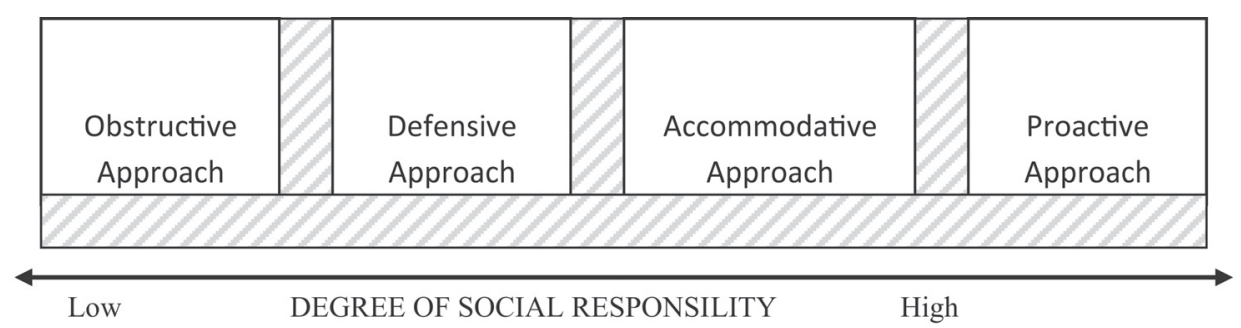

Source: Adapted from Jones and George (2003). Management. Boston: McGraw-Hill Irwin. p. 103.

According to Jones and George (2003), when a stakeholder group makes demands on a firm, management should first perform an analysis of the stakeholder by answering the following questions:

1. Who are the stakeholders?

2. How are the stakeholders affected by the company policies? 
3. What are the stakeholders' interests in the business?

4. In what way have the stakeholders behaved in the past?

5. How effective have the company's strategies been in dealing with these and other stakeholders?

6. What new strategies and action plans need to be formulated to deal effectively with the stakeholders?

Once an audit of the stakeholders has been done, the management can develop strategies for dealing with the stakeholders by selecting one of the following four general approaches: obstructive, defensive, accommodative, and proactive.

Obstructive Approach: At the lowest end of the continuum is the obstructive approach. Managers following this approach will not want to behave in a socially responsible way towards their stakeholders. Rather, they behave unethically and illegally and do everything possible to conceal their behaviour from reaching other organisational stakeholders and the society at large.

Defensive Approach: This approach indicates at least a commitment to ethical behaviour. Managers believe that they have an obligation to obey the law. That is, the only appropriate socially responsible behaviour is that prescribed by the law. Defensive managers perform their CSR within the limits of the law. Therefore, defensive managers have little active interest in social responsibility (Jones \& George, 2003).

Accommodative Approach: This approach is used when managers decide to accept social responsibility for business decisions, although they may do so in response to external pressures from stakeholder groups. Accommodative managers believe that organisations ought to behave in a socially responsible manner and that they must balance the interests of shareholders and stakeholders (Jones \& George, 2003). Managers adopting this strategy want to make choices that are reasonable in the eyes of the society and want to do the right thing when called on to do so.

Proactive Approach: Managers using a proactive approach take the lead in social issues. They seek to learn what is in the public interest and respond without pressure from any quarter. They actively engage in socially responsible activities and are willing to utilise organisational resources to promote the interests not only of shareholders but of other stakeholders (Jones \& George, 2003). One important example of a proactive response is corporate philanthropy.

\section{METHODOLOGY}

Survey research design method was used. The study population of this research work is the totality of all staff involved in CSR activities of selected commercial banks and manufacturing firms. The sample size for this study was determined by the following formula as suggested by Krejcie and Morgan (1970). $s=X^{2} N P(1-P) \div d^{2}(N$ $-1)+X^{2} P(1-P)$. 
Where: $s=$ required sample size.

$\mathrm{d}=$ degree of accuracy expressed as a proportion (0.05).

$\mathrm{N}=$ the population size.

$\mathrm{P}=$ the population proportion (assumed to be 0.50 since this would provide the maximum sample size).

The total number of staff involved in the determination of the CSR activities of commercial banks is 480 . Referring to the formula, the sample size for commercial banks is:

$$
\begin{aligned}
& s=X^{2} N P(1-P) \div d^{2}(N-1)+X^{2} P(1-P), \mathrm{N}=480, \mathrm{X}^{2}=3.841, \mathrm{P}=0.50 \text { and } \mathrm{d}=0.05 . \\
& =(3.841)(480 \mathrm{x} .50)(1-.50) / .05^{2}(480-1)+3.841 \mathrm{x} .50(1-.50)=213.6114008 \approx 214 .
\end{aligned}
$$

Thus, the sample size for commercial banks is 214 staff. However, 216 staff were used for the analysis. In the same vein, the total number of staff involved in the determination of CSR activities of manufacturing firms is 440 . Referring to the formula, the sample size is:

$$
\begin{aligned}
& s=X^{2} N P(1-P) \div d^{2}(N-1)+X^{2} P(1-P), \mathrm{N}=440, \mathrm{X}^{2}=3.841, \mathrm{P}=0.50 \text { and } \mathrm{d}=0.05 . \\
& =(3.841)(440 \mathrm{x} .50)(1-0.50) / .05^{2}(440-1)+3.841 \mathrm{x} .50(1-.50)=205.326 \approx 205 .
\end{aligned}
$$

Thus, the sample size for manufacturing firms is 205 staff.

In selecting the sample, the purposive sampling method was used. The sample selection is therefore the result of the researchers' opinion as to which elements best provide the desired basis and the probability of a good outcome (Ojo, 2003). The response structure for the questionnaire followed the Rensis Liket's summated rating scale of 1 to 5 points where $1=$ Strongly Disagree; $2=$ Disagree; $3=$ Undecided; $4=$ Agree; and $5=$ Strongly Agree. The data collected from the questionnaire were analysed, summarised, and interpreted accordingly with the aid of descriptive statistical techniques such as the total score and the simple percentage. The Mann-Whitney U Test was used as the analytical tool for secondary data and to prove the level of significance in testing the stated hypothesis.

\section{DATA ANALYSIS}

The respondents' feedback about the problems militating against the practice of CSR by commercial banks and manufacturing firms are presented in Table 1 and discussed in the few paragraphs that follow. 
Table 1: Problems Militating against the Practice of Corporate Social Responsibility by Commercial Banks and Manufacturing Firms

\begin{tabular}{|l|c|c|c|c|c|c|c|c|c|c|}
\hline & \multicolumn{3}{|c|}{ Commercial Banks (\%) } & \multicolumn{3}{c|}{ Manufacturing Firms (\%) } \\
\hline Variables & SA & A & U & D & SD & SA & A & U & D & SD \\
\hline Lack of time. & 8.4 & 16.7 & 15.3 & 28.8 & 30.7 & 8.8 & 16.6 & 15.1 & 30.7 & 28.8 \\
\hline Inadequate financial resources/lack of funds. & 37.2 & 29.3 & 13.5 & 10.2 & 9.8 & 38.5 & 31.2 & 13.2 & 8.3 & 8.8 \\
\hline Absence of government support. & 35.3 & 58.1 & 3.3 & 1.9 & 1.9 & 36.1 & 57.6 & 3.4 & 1.5 & 2.0 \\
\hline $\begin{array}{l}\text { Ignorance of the benefits associated with CSR } \\
\text { activities. }\end{array}$ & 8.8 & 21.9 & 24.2 & 30.7 & 14.4 & 9.3 & 22.0 & 23.9 & 30.7 & 14.1 \\
\hline $\begin{array}{l}\text { Lack of know-how for establishment of CSR in } \\
\text { the organisation. }\end{array}$ & 0.0 & 27.0 & 24.2 & 25.6 & 11.6 & 0.0 & 27.8 & 23.9 & 25.4 & 11.7 \\
\hline $\begin{array}{l}\text { Profit maximisation pursuit by Nigerian } \\
\text { managers. }\end{array}$ & 42.3 & 42.3 & 11.2 & 2.8 & 1.4 & 42.4 & 42.0 & 11.7 & 2.4 & 1.5 \\
\hline $\begin{array}{l}\text { Unethical practises like inside dealings and } \\
\text { embezzlement. }\end{array}$ & 46.0 & 34.0 & 15.3 & 3.3 & 1.4 & 46.8 & 33.2 & 15.6 & 2.9 & 1.5 \\
\hline Lack of information on CSR. & 8.8 & 19.1 & 15.8 & 35.8 & 20.5 & 8.3 & 17.6 & 16.1 & 37.1 & 21.0 \\
\hline CSR not related to the activities of the firm. & 0.5 & 14.4 & 41.9 & 33.5 & 9.8 & 0.5 & 15.1 & 42.0 & 32.2 & 10.2 \\
\hline $\begin{array}{l}\text { Absence of public support for CSR activities of } \\
\text { the firm. }\end{array}$ & 0.5 & 18.7 & 52.3 & 19.6 & 8.9 & 0.5 & 16.1 & 53.7 & 20.0 & 9.8 \\
\hline CSR behaviour does not benefit the firm at all. & 11.6 & 17.7 & 23.3 & 30.7 & 16.7 & 9.8 & 18.5 & 23.9 & 31.2 & 16.6 \\
\hline Lack of human resources. & 1.4 & 25.1 & 31.6 & 21.9 & 20.0 & 1.5 & 24.9 & 31.7 & 22.4 & 19.5 \\
\hline Lack of employee motivation. & 16.3 & 24.7 & 40.0 & 11.2 & 7.9 & 15.6 & 23.9 & 41.0 & 11.7 & 7.8 \\
\hline
\end{tabular}

Source: Author's Computation, 2016

Lack of Time: Respondents were asked to indicate if lack of time is another problem militating against the practice of CSR by commercial banks and manufacturing firms. Among the respondents from commercial banks, $8.4 \%$ and $16.7 \%$ respectively strongly agreed and agreed. $15.3 \%$ of them were undecided about the statement. $28.8 \%$ and $30.7 \%$ respectively disagreed and strongly disagreed with the statement. As for respondents from the manufacturing firms, $8.8 \%$ and $16.6 \%$ respectively strongly disagreed and disagreed with the statement. $15.1 \%$ of them were undecided about the statement. $30.7 \%$ and $28.8 \%$ of them respectively disagreed and strongly disagreed with the statement. From the above analysis, it can be concluded that lack of time is not a problem militating against the practice of CSR by commercial banks and manufacturing firms. This is because the majority of the respondents from commercial banks and manufacturing firms disagreed and strongly disagreed with the issue of lack of time.

Inadequate Financial Resources/Lack of Funds: Respondents also gave their opinion about whether inadequate financial resources/lack of funds is one of the problems militating against the practice of CSR by commercial banks and manufacturing firms. $37.2 \%$ and $29.3 \%$ of the respondents from commercial banks respectively strongly agreed and agreed with the statement. $13.5 \%$ of them were undecided. $10.2 \%$ and $9.8 \%$ of them respectively strongly agreed and disagreed with the statement. Among the re- 
spondents from manufacturing firms, $38.5 \%$ and $31.2 \%$ of them respectively strongly agreed and agreed with the statement. $13.2 \%$ of them were undecided about the statement. $8.3 \%$ of the respondents disagreed with the statement. The remaining $8.8 \%$ of the respondents strongly disagreed with the statement. The conclusion that can be deduced is that since the majority of the respondents from commercial banks (66.5\%) strongly agreed and agreed with the statement, and the majority of the respondents (69.7\%) from manufacturing firms strongly agreed and agreed with the statement, inadequate financial resources/lack of funds is one of the problems militating against the practice of CSR by commercial banks and manufacturing firms.

Absence of Government Support: As regards the absence of government support, $35.3 \%$ and $58.1 \%$ of the respondents from commercial banks respectively strongly agreed and agreed. 3.3\% of them were undecided about the statement. $1.9 \%$ and $1.9 \%$ respectively disagreed and strongly disagreed. Concerning the respondents from manufacturing firms, $36.1 \%$ and $57.6 \%$ of the respondents respectively strongly agreed and agreed with the statement. $3.4 \%$ of the respondents were undecided about the statement. $1.5 \%$ of the respondents disagreed with the statement. The remaining $2.0 \%$ of the respondents strongly disagreed with the statement. It can therefore be concluded that the absence of government support is one of the problems militating against the practice of CSR by commercial banks and manufacturing firms.

Ignorance of the Benefits Associated with CSR Activities: Respondents were asked if ignorance of the benefits associated with CSR activities is one of the problems militating against the practice of CSR by commercial banks and manufacturing firms. $8.8 \%$ and $21.9 \%$ of the respondents from commercial banks respectively strongly agreed and agreed with the statement. $24.2 \%$ of the respondents were undecided. $30.7 \%$ and $14.4 \%$ of them disagreed and strongly disagreed with the statement. As regards respondents from manufacturing firms, $9.3 \%$ and $22.0 \%$ of them respectively strongly agreed and agreed with the statement. $23.9 \%$ of them were undecided either for or against the statement. $30.7 \%$ of the respondents disagreed with the statement. However, $14.1 \%$ of the respondents strongly disagreed with the statement. Based on this analysis, it can be concluded that ignorance of the benefits associated with CSR activities is not one of the problems militating against the practice of CSR by commercial banks and manufacturing firms.

Lack of Know-how for Establishment of CSR in the Organisation: Respondents were asked if the lack of know-how for the establishment of CSR in the organisation is one of the problems militating against the practice of CSR by commercial banks and manufacturing firms. None of the respondents from commercial banks strongly agreed with the statement while $27.0 \%$ of them agreed with the statement. $24.2 \%$ of the respondents were undecided about the statement. $25.6 \%$ and $11.6 \%$ of the respondents respectively disagreed and strongly disagreed with the statement. Of the respondents from manufacturing firms, none of them strongly agreed with the statement while $27.8 \%$ of them agreed with the statement. $23.9 \%$ of the respondents were undecided about the statement. $25.4 \%$ and $11.7 \%$ of the respondents respectively disagreed and strongly disagreed with the statement. From this analysis, it can be inferred that lack of 
know-how for the establishment of CSR in the organisation is not one of the problems militating against the practice of CSR by commercial banks and manufacturing firms.

Profit Maximisation Pursuit by Nigerian Managers: Respondents from commercial banks and manufacturing firms gave their opinions about the issue of profit maximisation pursuit by Nigerian managers. $42.3 \%$ and $42.3 \%$ of the respondents from commercial banks respectively strongly agreed and agreed with the statement. $11.2 \%$ of the respondents were undecided about the statement. $2.8 \%$ and $1.4 \%$ of the respondents respectively disagreed and strongly disagreed. Of the respondents from manufacturing firms, $42.4 \%$ and $42.0 \%$ of them respectively strongly agreed and agreed with the statement. $11.7 \%$ of them were undecided about the statement. $2.4 \%$ and $1.5 \%$ of the respondents respectively disagreed and strongly disagreed with the statement. Based on the analysis in which the majority of the respondents from commercial banks and manufacturing firms strongly agreed and agreed with the statement, it can be inferred that profit maximisation pursuit by Nigerian managers is one of the problems militating against the practice of CSR by commercial banks and manufacturing firms.

Unethical Practices like Inside Dealings and Embezzlement: Respondents were asked whether the presence unethical practices like inside dealings and embezzlement is one of the problems militating against the practice of CSR by commercial banks and manufacturing firms. $46.0 \%$ and $34.0 \%$ of the respondents from commercial banks respectively strongly agreed and agreed with the statement. $15.3 \%$ of them were undecided either for or against the statement. 3.3\% and $1.4 \%$ of them respectively disagreed and strongly disagreed with the statement. Among the respondents from manufacturing firms, $46.8 \%$ and $33.2 \%$ of them respectively strongly agreed and agreed with the statement. $15.6 \%$ of them were undecided about the statement. $2.9 \%$ of the respondents disagreed with the statement. $1.5 \%$ of the respondents strongly disagreed with the statement. Based on the above analysis, it is pellucid that majority of the respondents from commercial banks and manufacturing firms strongly agreed and agreed with the statement. Thus, it can be inferred that the presence of unethical practices like inside dealings and embezzlement is one of the problems militating against the practice of CSR by commercial banks and manufacturing firms.

Lack of Information on Corporate Social Responsibility: In addition, respondents were asked if lack of information on CSR is one of the factors militating against the practice of CSR by commercial banks and manufacturing firms. $8.8 \%$ and $19.1 \%$ of the respondents from commercial banks respectively strongly agreed and agreed with the statement. $15.8 \%$ of them were undecided either for or against the statement. $35.8 \%$ and $20.5 \%$ of the respondents respectively disagreed and strongly disagreed with the statement. Among the respondents from manufacturing firms, $8.3 \%$ and $17.6 \%$ of them respectively strongly agreed and agreed. $17.6 \%$ of them were undecided, while $37.1 \%$ and $21.0 \%$ of them respectively disagreed and strongly disagreed with the statement. The conclusion that can be deduced from the above evidence is that lack of information on corporate social responsibility is not one of the problems militating against the practice of CSR by commercial banks and firms. 
CSR Not Related to the Activities of the Firms: Respondents were also asked whether CSR is related to the activities of the firms. $0.5 \%$ and $14.4 \%$ of the respondents from commercial banks respectively strongly agreed and agreed with the statement. $41.9 \%$ of them were undecided about the statement. $33.5 \%$ and $9.8 \%$ of the respondents respectively disagreed and strongly disagreed with the statement. Among the respondents from manufacturing firms, $0.5 \%$ and $15.1 \%$ of them respectively strongly agreed and agreed with the statement. $42.0 \%$ of them were undecided about the statement. $32.2 \%$ of the respondents disagreed with the statement. $10.2 \%$ of the respondents strongly disagreed with the statement. The conclusion that can be drawn is that since many respondents disagreed and strongly disagreed with the statement, the researcher can infer that CSR is related to the activities of commercial banks and manufacturing firms as CSR initiatives of these companies are well detailed in their published annual reports and accounts.

Absence of Public Support for CSR Activities of the Firms: In addition, respondents were asked to give their view about the absence of public support of CSR activities of the firms under study. $0.5 \%$ and $18.7 \%$ of the respondents respectively strongly agreed and agreed with the statement. $52.3 \%$ of them were undecided about the statement. $19.6 \%$ and $8.9 \%$ of them respectively disagreed and strongly disagreed with the statement. Of the respondents from manufacturing firms, $0.5 \%$ and $16.1 \%$ of them respectively strongly agreed and agreed with the statement. $53.7 \%$ of them were undecided about the statement. $20 \%$ of the respondents disagreed with the statement. $9.8 \%$ of the respondents strongly disagreed with the statement. The majority of the respondents from commercial banks and manufacturing firms were undecided about the statement. Next, $28.8 \%$ of the respondents from commercial banks and $29.8 \%$ of the respondents from manufacturing firms disagreed and strongly disagreed with the statement. The inference that can be drawn is that the absence of public support for CSR activities of the firms is not one of the problems militating against the practice of CSR by commercial banks and manufacturing firms.

CSR Behaviour does not Benefit the Firm at all: In addition, respondents were asked to give their viewpoint on the statement that CSR behaviour does not benefit the firm at all. $11.6 \%$ and $17.7 \%$ of the respondents from commercial banks respectively strongly agreed and agreed with the statement. $23.35 \%$ of the respondents were undecided about the statement. $30.7 \%$ and $16.7 \%$ of the respondents respectively disagreed and strongly disagreed with the statement. Among the respondents from manufacturing firms, $9.8 \%$ and $18.5 \%$ of them respectively strongly agreed and agreed with the statement. $23.9 \%$ of them were undecided about the statement. $31.2 \%$ and $16.6 \%$ of them respectively disagreed and strongly disagreed with the statement. Based on the above analysis, it can be concluded that CSR behaviour does benefit the firm and that it does not constitute one of the problems militating against the practice of CSR by commercial banks and manufacturing firms.

Lack of Human Resources: Respondents were also asked if the lack of human resources is one of the problems militating against the practice of CSR by commercial banks and manufacturing firms. $1.4 \%$ and $25.1 \%$ of the respondents from commercial 
banks respectively strongly agreed and agreed with the statement. $31.6 \%$ of them were undecided about the statement. $21.9 \%$ and $20 \%$ of them respectively disagreed and strongly disagreed with the statement. Among the respondents from manufacturing firms, $1.5 \%$ and $24.9 \%$ of them respectively strongly disagreed and disagreed with the statement. $31.7 \%$ of them were undecided about the statement. 22.45 and $19.5 \%$ of them respectively disagreed and strongly disagreed with the statement. From this analysis, it can be inferred that the lack of human resources is not one of the problems militating against the practice of CSR by commercial banks and manufacturing firms. The reason is that the majority of the respondents disagree and strongly disagree with the statement.

Lack of Employee Motivation: In addition, respondents from both commercial banks and manufacturing firms were asked whether the lack of employee motivation is one of the factors militating against the practice of CSR. $16.3 \%$ and $24.7 \%$ of the respondents from commercial banks respectively strongly agreed and agreed with the statement. $40 \%$ of them were undecided about the statement. $11.2 \%$ and $7.9 \%$ of the respondents respectively disagreed and strongly disagreed with the statement. As regards the respondents from manufacturing firms, $15.6 \%$ and $23.9 \%$ of them respectively strongly agreed and agreed with the statement. $41 \%$ of them were undecided about the statement. $11.7 \%$ and $7.8 \%$ of them disagreed and strongly disagreed with the statement. Since a larger percentage of the respondents strongly agreed and agreed with the statement than the percentage of the respondents that disagreed and strongly disagreed, the researcher concluded that the lack of employee motivation constitutes one of the problems militating against the practice of CSR by commercial banks and manufacturing firms.

\section{TESTING OF HYPOTHESIS}

Ho: There is no significant difference between the problems militating against the practice of CSR by commercial banks and manufacturing firms in Nigeria.

$$
\begin{aligned}
& \mathrm{Y}=\mathrm{f}(\mathrm{X}) \\
& \mathrm{CSR}=\mathrm{f}(\mathrm{NOTIME}+\mathrm{NOFUND+GOVSUP+IGNORAN+NOKNOW+PROFIT+} \\
& \text { UNETHIC+NOINFO+NONACT+PUBSUP+NOBENEF+NOPERS+NOMOT) }
\end{aligned}
$$

Hence, the model becomes:

$$
\begin{aligned}
& \text { CSR }=\left(\beta_{0}+\beta_{1} \text { NOTIME }_{1}+\beta_{2} \text { NOFUND }_{2}+\beta_{3} \text { GOVSUP }_{3}+\beta_{4} \text { IGNORAN }_{4}+\right. \\
& \beta_{5} \text { NOKNOW }_{5}+\beta_{6} \text { PROFIT }_{6}+\beta_{7} \text { UNETHIC }_{7}+\beta_{8} \text { NOINFO }_{8}+\beta_{9} \text { NONACT }_{9}+ \\
& \left.\beta_{10} \text { PUBSUP }_{10}+\beta_{11} \text { NOBENEF }_{12}+\beta_{12} \text { NOPERS }_{12}+\beta_{13} \text { NOMOT }_{13}+\mathrm{e}\right)
\end{aligned}
$$

Where:

NOTIME $=$ Lack of time.

NOFUND $=$ Absence of government support . 
GOVSUP $=$ Inadequate financial resources/lack of funds.

IGNORAN= Ignorance of the benefits associated with CSR activities.

NOKNOW= Ignorance of the benefits associated with CSR activities.

PROFIT $=$ Profit maximisation pursuit by Nigerian managers.

$\mathrm{UNETHIC}=$ Unethical practises like inside dealings and embezzlement.

$\mathrm{NOINFO}=$ Lack of information on corporate social responsibility.

NONACT $=$ CSR not related to the activities of the firm.

PUBSUP $=$ Absence of public support for CSR activities of the firm.

NOBENEF $=$ CSR behaviour does not benefit firms at all.

NOPERS $=$ Lack of human resources.

NOMOT $=$ Lack of employee motivation.

$e=$ Error term.

Table 2: Ranks of the Factors Militating against the Practice of CSR by Commercial Banks and Manufacturing Firms in Nigeria Using Mann-Whitney U Test.

\begin{tabular}{|c|c|c|c|c|}
\hline & Organisation & $\mathrm{N}$ & Mean Rank & Sum of Ranks \\
\hline \multirow{3}{*}{ Lack of time. } & Commercial Banks & 216 & 210.73 & 45517.00 \\
\hline & Manufacturing Firms & 205 & 211.29 & 43314.00 \\
\hline & Total & 421 & & \\
\hline \multirow{3}{*}{$\begin{array}{l}\text { Inadequate financial resources/lack } \\
\text { of funds. }\end{array}$} & Commercial Banks & 216 & 208.40 & 45014.50 \\
\hline & Manufacturing Firms & 205 & 213.74 & 43816.50 \\
\hline & Total & 421 & & \\
\hline \multirow{3}{*}{ Absence of government support. } & Commercial Banks & 216 & 212.81 & 45966.50 \\
\hline & Manufacturing Firms & 205 & 209.10 & 42864.50 \\
\hline & Total & 421 & & \\
\hline \multirow{3}{*}{$\begin{array}{c}\text { Ignorance of the benefits associated } \\
\text { with CSR activities. }\end{array}$} & Commercial Banks & 216 & 210.65 & 45500.50 \\
\hline & $\begin{array}{l}\text { Manufacturing } \\
\text { Companies }\end{array}$ & 205 & 211.37 & 43330.50 \\
\hline & Total & 421 & & \\
\hline \multirow{3}{*}{$\begin{array}{l}\text { Lack of know-how for establishment } \\
\text { of CSR in the organization. }\end{array}$} & Commercial Banks & 216 & 211.56 & 45696.50 \\
\hline & Manufacturing Firms & 205 & 210.41 & 43134.50 \\
\hline & Total & 421 & & \\
\hline \multirow{3}{*}{$\begin{array}{l}\text { Profit maximisation pursuit by Nigerian } \\
\text { managers. }\end{array}$} & Commercial Banks & 216 & 212.00 & 45792.50 \\
\hline & Manufacturing Firms & 205 & 209.94 & 43038.50 \\
\hline & Total & 421 & & \\
\hline \multirow{3}{*}{$\begin{array}{l}\text { Unethical practices like inside dealings } \\
\text { and embezzlement. }\end{array}$} & Commercial Banks & 216 & 211.12 & 45601.50 \\
\hline & Manufacturing Firms & 205 & 210.88 & 43229.50 \\
\hline & Total & 421 & & \\
\hline
\end{tabular}


Table 2 - Continued

\begin{tabular}{|c|c|c|c|c|}
\hline & Organisation & $\mathrm{N}$ & Mean Rank & Sum of Ranks \\
\hline \multirow{3}{*}{$\begin{array}{l}\text { Lack of information on corporate } \\
\text { social responsibility. }\end{array}$} & Commercial Banks & 216 & 213.82 & 46186.00 \\
\hline & Manufacturing Firms & 205 & 208.02 & 42645.00 \\
\hline & Total & 421 & & \\
\hline \multirow{3}{*}{$\begin{array}{l}\text { CSR not related to the activities of } \\
\text { the firm. }\end{array}$} & Commercial Banks & 216 & 209.94 & 45346.50 \\
\hline & Manufacturing Firms & 205 & 212.12 & 43484.50 \\
\hline & Total & 421 & & \\
\hline \multirow{3}{*}{$\begin{array}{c}\text { Absence of public support for CSR } \\
\text { activities of the firm. }\end{array}$} & Commercial Banks & 216 & 213.66 & 46150.00 \\
\hline & Manufacturing Firms & 205 & 208.20 & 42681.00 \\
\hline & Total & 421 & & \\
\hline \multirow{3}{*}{$\begin{array}{l}\text { CSR behaviour does not benefit the } \\
\text { firm at all. }\end{array}$} & Commercial Banks & 216 & 210.73 & 45517.50 \\
\hline & Manufacturing Firms & 205 & 211.29 & 43313.50 \\
\hline & Total & 421 & & \\
\hline \multirow{3}{*}{ Lack of human resources. } & Commercial Banks & 216 & 210.77 & 45526.50 \\
\hline & Manufacturing Firms & 205 & 211.24 & 43304.50 \\
\hline & Total & 421 & & \\
\hline \multirow{3}{*}{ Lack of employee motivation. } & Commercial Banks & 216 & 211.33 & 45646.50 \\
\hline & Manufacturing Firms & 205 & 210.66 & 43184.50 \\
\hline & Total & 421 & & \\
\hline
\end{tabular}

Source: Author' Computation, 2016.

Table 3: Test Statistics of Problems Militating against the Practice of CSR by Commercial Banks and Manufacturing Firms in Nigeria Using the Mann-Whitney U Test.

\begin{tabular}{|c|c|c|c|c|c|c|c|c|c|c|c|c|c|}
\hline & NOTIME & NOFUND & GOVSUP & IGNORAN & NOKNOW & PROFIT & UNETHIC & NOINFO & NONACT & PUBSUP & NOBENEF & NOPERS & NOMOT \\
\hline Mann-Whitney U & 22081.000 & 21578.500 & 21749.500 & 22064.500 & 22019.500 & 21923.500 & 22114.500 & 21530.000 & 21910.500 & 21566.000 & 22081.500 & 22090.500 & 22069.500 \\
\hline Wilcoxon W & 45517.000 & 45014.500 & 42864.500 & 45500.500 & 43134.500 & 43038.500 & 43229.500 & 42645.000 & 45346,500 & 42681.000 & 45517,500 & 45526,500 & 43184.500 \\
\hline z & .049 & .470 & .343 & .062 & .099 & . 189 & $: 022$ & .506 & .195 & .503 & .048 & $: 041$ & .059 \\
\hline $\begin{array}{l}\text { Asymp. Sig. } \\
\text { (2-taliled) }\end{array}$ & .961 & .638 & .732 & .950 & .921 & .850 & .982 & .613 & .845 & .615 & .962 & .967 & .953 \\
\hline
\end{tabular}

a. Grouping Variable: Organisation

Source: Author's Computation, 2016.

Table 2 and Table 3 were the outputs generated when Mann-Whitney U Test was used to test hypothesis three. Both the outputs of the ranks and test statistics were considered in this analysis. The mean rank score for commercial banks under lack of time was 210.73 , while the mean rank score for manufacturing firms was 211.29. The $\mathrm{z}$ value $=$ -.049 with a significant level of $\mathrm{p}=.961$. The probability value $(\mathrm{p})$ is not less than or equal to .05 , so the result is not significant. There is no statistically significant difference in lack of time scores of commercial banks and manufacturing firms. 
In addition, the mean rank score for commercial banks under inadequate financial resources/lack of funds was 208.40, while the mean rank score for manufacturing firms was 213.74 . The $\mathrm{z}$ value $=-.470$ with a significant level of $\mathrm{p}=.638$. The probability value (p) is not less than or equal to .05 , so the result is not significant. There is no statistically significant difference in inadequate financial resources/lack of funds scores of commercial banks and manufacturing firms.

When considering the absence of government support, the mean rank score for commercial banks was 212.81 while the mean rank score for manufacturing firms was 209.10. The $\mathrm{z}$ value $=-.343$ with a significant level of $\mathrm{p}=.732$. The probability value ( $\mathrm{p}$ ) is not less than or equal to .05 , so the result is not significant. There is no statistically significant difference in the absence of government support scores of commercial banks and manufacturing firms.

Ignorance of the benefits associated with CSR activities was considered; the mean rank score for commercial banks was 210.65 while the mean rank score for manufacturing firms was 211.37. The $\mathrm{z}$ value $=-.062$ with a significant level of $\mathrm{p}=.950$. The probability value $(\mathrm{p})$ is not less than or equal to .05 , so the result is not significant. There is no statistically significant difference in ignorance of the benefits associated with CSR activities scores of commercial banks and manufacturing firms.

When the lack of know-how for establishment of CSR in the organisation was considered as a problem militating against the practice of CSR, the mean rank score for commercial banks and manufacturing firms respectively were 211.56 and 210.41 . The $\mathrm{z}$ value $=-.099$ with a significant level of $\mathrm{p}=.921$. The probability value $(\mathrm{p})$ is not less than or equal to .05 , so the result is not significant. There is no statistically significant difference in lack of know-how for the establishment of CSR in the organisation scores of commercial banks and manufacturing firms.

Furthermore, profit maximisation pursuit by Nigerian managers was taken into consideration; the mean rank score for commercial banks was 212.00 while the mean rank score for manufacturing firms was 209.94. The $\mathrm{z}$ value $=-.189$ with a significant level of $\mathrm{p}=.850$. The probability value ( $\mathrm{p}$ ) is not less than or equal to .05 , so the result is not significant. There is no statistically significant difference in profit maximisation pursuit by Nigerian managers scores of commercial banks and manufacturing firms.

Another point taken into consideration were unethical practices like inside dealings and embezzlement. The commercial banks' mean rank score was 211.12 while mean rank score for manufacturing firms was 210.88 . The $\mathrm{z}$ value $=-.022$ with a significant level of $\mathrm{p}=.982$. The probability value $(\mathrm{p})$ is not less than or equal to .05 , so the result is not significant. There is no statistically significant difference in unethical practices like inside dealings and embezzlement scores of commercial banks and manufacturing firms.

In the same vein, the lack of information on CSR was considered. The mean rank score for commercial banks was 213.82 while the mean rank score for manufacturing firms was 208.02. The $\mathrm{z}$ value $=-.506$ with a significant level of $\mathrm{p}=.613$. The probability value (p) is not less than or equal to .05 , so the result is not significant. There is no statis- 
tically significant difference in lack of information on CSR scores of commercial banks and manufacturing firms.

The mean rank score for commercial banks under CSR is not related to the activities of the firm was 209.94, while the mean rank score for manufacturing firms was 212.12. The $\mathrm{z}$ value $=-.195$ with a significant level of $\mathrm{p}=.845$. The probability value $(\mathrm{p})$ is not less than or equal to .05 , so the result is not significant. There is no statistically significant difference in CSR is not related to the activities of the firm scores of commercial banks and manufacturing firms.

In addition, the mean rank score for commercial banks as regards the absence of public support for CSR activities of the firm was 213.66, while the mean rank score for manufacturing firms was 208.20. The $\mathrm{z}$ value $=-.503$ with a significant level of $\mathrm{p}=.615$. The probability value $(\mathrm{p})$ is not less than or equal to .05, so the result is not significant. There is no statistically significant difference in absence of public support for CSR activities of the firm scores of commercial banks and manufacturing firms.

When considering CSR behaviour does not benefit the firm at all, the mean rank score for commercial banks was 210.73 while the mean rank score for manufacturing firms was 211.29 . The $\mathrm{z}$ value $=-.048$ with a significant level of $\mathrm{p}=.962$. The probability value (p) is not less than or equal to .05, so the result is not significant. There is no statistically significant difference in CSR behaviour does not benefit the firms at all scores of commercial banks and manufacturing firms.

Lack of human resources was considered; the mean rank score for commercial banks was 210.77 while the mean rank score for manufacturing firms was 211.24. The $\mathrm{z}$ value $=-.041$ with a significant level of $\mathrm{p}=.967$. The probability value $(\mathrm{p})$ is not less than or equal to .05 , so the result is not significant. There is no statistically significant difference in lack of human resources scores of commercial banks and manufacturing firms.

Additionally, the mean rank score for commercial banks as regards the lack of employee motivation was 211.33, while the mean rank score for manufacturing firms was 210.66 . The $z$ value $=-.059$ with a significant level of $p=.953$. The probability value (p) is not less than or equal to .05, so the result is not significant. There is no statistically significant difference in lack of employee motivation scores of commercial banks and manufacturing firms.

From the above analysis, it is pellucid that there is no significant difference in the problems militating against the practice of CSR by commercial banks and manufacturing firms. The null hypothesis is accepted. The reason for this assertion is that for any statistics to be significant, the p value should be less than or equal to 0.05 .

\section{CONCLUSIONS}

The research finding has established that there is no significant difference between the problems militating against the practice of CSR in selected commercial banks and manufacturing firms in Nigeria. This is evidenced by the analysed data which 
showed that the $\mathrm{p}$ value is greater than 0.05 in all situations. Based on this, the null hypothesis is accepted.

The review of literature on CSR revealed that CSR activities are important tools that can make an organisation visible in the environment where they operate. In addition to this, CSR initiatives also serve as channels through which corporate organisations make a positive impact on their environment and by doing so, they create goodwill and a public image as well as meet the public expectations of their stakeholders. Corporate managers in Nigeria should realise that business organisations make demands on the society, and vice-versa. Business needs the support of the society in order to grow and thrive while the society needs business organisations in terms of goods and services they provide. The idea of social responsibility implies that in addition to the pursuit of their organisational goals, business organisations should assist the society especially because their actions sometimes produce negative consequences for it. If any organisation fails in its social responsibility, such an organisation may face sanction from the government as well as stiff opposition by the society. It is recommended that corporate organisations should be mindful of these problems that militate against their involvement in CSR and provide workable solutions so that they can be socially responsible in their environment.

\section{REFERENCES:}

1. Amaeshi, K. M., Adi, B. C., Ogbechie, C. \& Amao, O. O. (2006). Corporate social responsibility in Nigeria: Western mimicry or indigenous influences? The Journal of Corporate Citizenship, 2(4), 83.

2. D’amato, A., Henderson, S.\& Florence, S. (2009). Corporate social responsibility and sustainable business. Greensboro: Centre for Creative Leadership. p. 29.

3. European Commission (2001). Green paper promoting a European framework for corporate social responsibility. Commission of the European Communities, Brussels. Available at http://eurex.europa.eu/LexUriServ/LexUriServ.do?uri=COM:2001: 0366: FIN:EN:PDF. (Accessed on 22nd June, 2016). p. 28.

4. Eweje, G. (2006). The role of MNEs in community development initiatives in developing countries: Corporate social responsibility at work in Nigeria and southern Africa. Business and Society, 45(2), 93-129.

5. Gobbels, M. (2002). Reframing corporate social responsibility: The contemporary conception of a fuzzy notion. (cited in VAN MARREWIJK, 2003). p. 53.

6. Henderson, D. (2001). Misguided virtue: False notions of corporate social responsibility. New Zealand: Business Roundtable. p. 23.

7. Idowu, A. (2012). Corporate social responsibility: Living up to the community expectations in business financing. International Research Journal of Humanities, $4(2), 43-50$. 
8. Idowu, A. (2014). Corporate social responsibility in Nigerian banking industry: When will the lip-service games end? Journal of Economics and Sustainable Development, 5(2), 21-26.

9. Jill, S. (2007). Corporate governance and accountability. West Sussex: John Willey. p. 56

10. Jones, G. R., \& George, J. M. (2003).Management.Boston: McGraw-Hill Irwin. p. 48.

11. Kreitner, R. (1995). Management. Boston: Houghton Mifflin Company. p.71.

12. Krejcie, R. V. \& Morgan, D. W. (1970). Determining sample size for research activities. Educational and Psychological Measurement, 30, 607-610.

13. Nwanji, T. I. (2005). Ethical implication of corporate governance: A deontological and teleological approach applying grounded theory. Unpublished PhD Thesis.Anglia Ruskin University, United Kingdom. p.18.

14. Nwanji, T. I., \& Howell, K. E. (2006).Overview of corporate social responsibility. London: Holborn College. p. 63.

15. Ojo, O. (2003). Fundamentals of research methods. Lagos: Standard Publications. p. 150.

16. Ojo, O. (2008). An appraisal of the practice of social responsibility by business organisations in Nigeria. Lex ET Scientia International Journal, XV(1), 155-165.

17. Ojo, O. (2015). Corporate social responsibility and sustainable development relationship: The case of selected commercial banks in Nigeria. In E. Druica (Ed.) The International Conference in Economics and Administration. University of Bucharest, pp. 254-263.

18. Van Marrewijk, M. (2003). Concepts and definitions of CSR and corporate sustainability between agency and communion. Journal of Business Ethics, 44(3), 95-104

19. Windersor, D. (2001). The future of corporate social responsibility.The International Journal of Organizational Analysis, 9(3), 225-256 
USPOREDNA ANALIZA PROBLEMA KOJI NEGATIVNO UTJEČU NA DRUŠTVENU ODGOVORNOST PODUZEĆA U ODABRANIM BANKAMA I PROIZVODNIM TVRTKAMA U NIGERIJI

\author{
Olu Ojo $^{2}$
}

\title{
Sažetak
}

Ovaj rad predstavlja usporednu analizu problema koji negativno utječu na društvenu odgovornost poduzeća u odabranim bankama i proizvodnim tvrtkama u Nigeriji. Metoda korištena u ovom istraživanju je anketa te je odabran namjerni uzorak od pet komercijalnih banaka i pet proizvodnih tvrtki. Primarni podaci prikupljeni su putem upitnika na koji se odazvalo 216 ispitanika iz komercijalnih banaka i 205 ispitanika iz proizvodnih tvrtki. Problemi koji negativno utječu na društveno odgovorno djelovanje odabranih kompanija analizirani su korištenjem Mann-Whitneyevog U testa kao analitičkog alata. Rezultati pokazuju da ne postoji značajna razlika između problema koji negativno utječu na praksu društvene odgovornosti u komercijalnim bankama i proizvodnim tvrtkama u Nigeriji. Razlog za to je što je p vrijednost za sve testirane varijable veća od 0.05. U radu se preporučuje da upravljačke strukture poduzeća pristupe rješavanju problema poput nedovoljnih financijskih sredstava ili neetičnog postupanja kao što je između ostaloga zloupotreba povlaštenih informacija, kako bi se ostvarile koristi aktivnog korištenja društveno odgovornih praksi kao što su vjernost klijenata i ugled poduzeća.

Ključne riječi: društvena odgovornost poduzeća, problemi s negativnim utjecajem, komercijalne banke, proizvodne tvrtke, Nigerija.

JEL klasifikacija: M14, A13, G21

\footnotetext{
2 Dr. sc. Olu, Odjel za poslovnu administraciju, Department of Business Administration. Faculty of Management Sciences, Osun State University, Okuku, Osun State, Nigeria, E-mail: oluojo@gmail.com; oluojoe@yahoo.com
} 